\title{
The inclusion of elderly persons from the Instituto Henrique da Silva Semente (IHESS) in Indaiatuba, São Paulo, in the digital age: physio-gerontological contributions
}

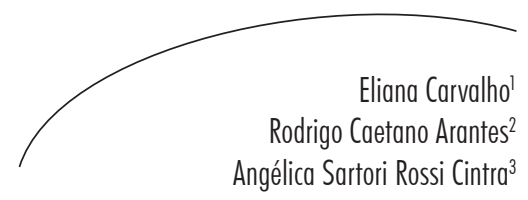

Resumo

Introduction: The evolution of information technologies has become part of our daily life and directly or indirectly affects the elderly population. The presence of these technologies, such as mobile phones, smartphones, computers, and tablets, at home where elderly persons live with their families demonstrates the necessity of including the elderly population in the technological universe. Objective: The aim of the present study was to describe the benefits obtained by the elderly from using such Information and Communication Technologies (ICTs), the effect of such use on their Activities of Daily Living (ADLs) and which physio-gerontological contributions resulted in the best use of the ICTs. Method: A convenience sample $(n=30)$ was performed of individuals aged over 60 years who were students at the Instituto Henrique da Silva Semente (IHESS). Demographic and social data, the Geriatric Depression Scale (GDS) and the Mini Mental State Examination (MMSE) were considered. The data was collected between April and May 2014. Results: The average age was 67.9 years with a predominance of women $(76.7 \%)$. Among the respondents $83.3 \%$ used a computer at home; $66.6 \%$ had some kind of difficulty in using computers; and $86.6 \%$ used ICTs in their daily lives. Despite the difficulties in using the devices resulting from the limitations imposed by age, it was observed that the equality of the age range encouraged interaction with friends and family, and as a result $100 \%$ of respondents displayed excellent interpersonal relationships with the class group. It was also observed that the elderly persons had a great desire to learn and interact through the use of technological devices, and that females were involved in recreational and educational activities, with wives encouraging their husbands to attend the computer class. However, there were exemplary risks of the misuse of these devices, such as poor posture when handling electronic devices or spending long spells in unsuitable positions, demonstrating the need for physical therapy and geriatric guidelines to ensure the wellbeing of the elderly. Conclusion: The inclusion of elderly persons in the IHESS or in any other educational activity should consider the familiar environment in which they live as well as providing professional support in physiotherapeutic and gerontologic areas in order to assure well-being and quality of life, especially at this stage of life, senescence.

\footnotetext{
Centro Dia Convida Day Care, Indaiatuba, SP, Brasil.

2 Conselho Estadual do Idoso de Minas Gerais, Belo Horizonte, MG, Brasil.

Faculdade Anhanguera de Campinas, Curso de Fisioterapia, Campinas, SP, Brasil.
}

Key words: Elderly; Aging; Digital Inclusion; Cognition; New Technologies. 


\section{INTRODUCTION}

The increased life expectancy of the world's population means that the elderly have become a central theme of discussions in various forms of media. Most of these discussions have focused on quality of life (QOL), with the aim of achieving a healthier aging process, with greater dependence for the elderly person. Additional years of life offer the elderly the opportunity to develop new activities, such as education or a new career, or the chance to develop in an area that they have neglected during life. Older people can also contribute to their families and communities in various manners. However, the extent of these opportunities and contributions strongly depends on one factor: health. ${ }^{1}$

With respect to the theme of digital inclusion, Chapter V"\$ 1 of the Estatuto do Idoso (the Statute of the Elderly), Decree No. 6214, $2007^{2}$ states that: "special courses for the elderly should include content on communication and computing techniques and other technological advances, for integration into modern life." In keeping with the provisions of the Statute and their increasing representation in an aging society, elderly persons aim to participate more effectively in activities related to the technological advances of the modern world. Considering the universe of elderly persons and their needs, it is clear that communication and social interaction are important processes for this group. ${ }^{3}$ Despite their difficulties, elderly persons have shown a great desire to be connected and, therefore, have attended information technology classes in order to become computer users and have fun, as well as engaging with colleagues and family through the most common forms of digital socialization.

The elderly, in their eagerness to use computers in their homes, may face problems due to the long periods spent in a sitting position that these devices promote among their users. A typical example refers to one's posture while sitting at the computer and the exaggerated use of smartphones.
Unsuitable postures when handling these devices can cause harm to users, especially the elderly, such as the acceleration of the loss of visual capacity, reduced fine motor skills due to the excessive use of a mouse, reduced cardiovascular circulation due to the time spent sitting, weakened abdominal muscles due to the curvature of the body during the operation of these devices, and pain in the cervical regions and/or lumbar. Roughly speaking, people should be aware of the type of work and/or leisure activity performed when using the computer, for example, with the aim of developing ways to adopt a correct and more ergonomic position to prevent disease. ${ }^{4}$ In this context, the present study aimed to understand what contributions digital inclusion can offer the elderly, what is the effect on their ADLs and what are the negative aspects, mainly postural, which may occur due to improper use of these devices. In the latter aspect, the intervention of a physiotherapist can be crucial to mitigate consequences arising from poor posture when using electronic devices.

\section{METHOD}

The present survey was submitted to the Research Ethics Committee of the Universidade Federal de São Carlos (the Federal University of São Carlos) (UFSCar) under number 823548. The survey, based on a convenience sample, was carried out between April and May 2014 with 30 elderly persons who complied with the inclusion criteria of being aged 60 years or older and who attended the Computer Workshop of the socialeducational institution the Instituto Henrique da Silva Semente (Henrique da Silva Semente Institute) (IHESS), located in Indaiatuba, in the Campinas Metropolitan Region. This municipal district has 225,974 inhabitants, $11.90 \%$ of whom are elderly. ${ }^{10}$

The elderly participants were informed about the research objectives and, after signing a Free and Informed Consent Form, were interviewed and assessed individually. 
The study, which was based on a convenience sample, was carried out between April and May 2014 with 30 elderly persons. The inclusion criteria elderly persons aged 60 years or more who attended the computer workshop of the socio-educational department of the Instituto Henrique da Silva Semente (IHESS) located in the city of Indaiatuba, in the metropolitan region of Campinas. This town has 225,974 inhabitants and an elderly population corresponding to $11.90 \% .{ }^{5}$

The survey adopted a qualitative approach and applied a semi-structured script, whose theme contemplated the following aspects: socioeconomic data; the main reasons that led the elderly person to attend the computer course; whether insertion in the computer course would have interfered with their previous physical activities; what were the main difficulties encountered in computer use; what other technologies did they frequently use in their ADLs; if the elderly person, once he or she had started to use these technologies, had had some kind of postural instruction to reduce the possible consequences resulting from the time spent in an improper position; the Geriatric Depression Scale ${ }^{6}$ (GDS) and Mini Mental State Examination (MMSE). ${ }^{7}$ The application of the
MMSE aimed to identify if there were cases of cognitive decline in the group. If such cases were identified, the values obtained from the respondent in question were not included in the search result. The survey was conducted by a geriatric physical therapist who as properly trained to perform such activities. The results were tabulated and presented in a descriptive manner, and were then converted into a sample percentage format for analysis.

\section{RESULTS}

Of the 30 respondents, $76.7 \%$ were women, of whom $63.3 \%$ were married, and the average age was 67.9 years. There was no record of illiteracy. All had a computer at home and $83.3 \%$ regularly used a computer, either to write texts or use social media. The remaining $16.7 \%$ did not use the computer mainly due to fear of breaking the machine, not knowing how to switch it on alone or because their children did not let them use it.

Table 1 shows the results of the survey of the reasons the elderly persons attended the computer course and whether it had resulted in a reduction in their previous physical activities.

Table 1. Reasons of respondents for attending the information technology course and interference in their previous physical activities, Instituto Henrique da Silva Semente (IHESS). Indaiatuba, São Paulo, 2014.

\begin{tabular}{lcc}
\multicolumn{1}{c}{ Variables } & N & $\%$ \\
\hline Reason for attending IHESS & & \\
A. Social Integration & 14 & 46.6 \\
B. Learning & 10 & 33.3 \\
C. Refreshing knowledge & 6 & 20.0 \\
Total & 30 & 100.0 \\
\hline If digital insertion had led to a reduction in previous physical activities & & \\
Did not participate in physical activities & 5 & 16.6 \\
Did not suffer any alteration in physical activities & 25 & 83.3 \\
Total & 30 & 100.0 \\
\hline
\end{tabular}

Source: survey performed by researchers at IHESS, 2014. 
The noteworthy result of $46.6 \%$ in "Social Integration" demonstrates the strong desire of the elderly to feel more present in society, yet without compromising the physical activities that they previously practiced regularly, which applied to $83.3 \%$ of respondents. In this sense, digital inclusion can add to and promote a better quality of social life.

As for the main difficulties encountered by the elderly in using computers, the most common were using a mouse, $60 \%$, and using the keyboard, $46 \%$, as shown in table 2 .

Table 2. Main difficulties in using computer, Instituto Henrique da Silva Semente (IHESS). Indaiatuba, São Paulo, 2014.

\begin{tabular}{lcc}
\multicolumn{1}{c}{ Variables } & N & $\%$ \\
\hline Do you have difficulties when using a computer & & \\
Yes & 20 & 66.6 \\
No & 10 & 33.3 \\
Principal difficulties reported & 18 & \\
Use of Mouse & 14 & 60.0 \\
Use of Keyboard & 4 & 46.6 \\
Screen brightness & 2 & 13.3 \\
Mouse double clicking & 1 & 6.6 \\
Selecting Text & 1 & 3.3 \\
Size of letters on screen & 30 & 3.3 \\
Total & & 100.0 \\
\hline
\end{tabular}

Source: survey performed by researchers at IHESS, 2014.

In addition to computer use, other devices are associated with digital inclusion, such as: mobile phone, bank ATMs, and tablets, where elderly persons seek not just to learn about the equipment, but also to master its logic and integrate themselves as an active and motivating part of society. Table 3 shows the main results regarding the use of other technologies in the daily life of the elderly persons: $100 \%$ made use of ATMs, $86.6 \%$ had a mobile phone and $63.3 \%$ made calls with their cell phones.

Table 3. Other Technologies used in the daily life of the elderly persons, Instituto Henrique da Silva Semente (IHESS). Indaiatuba, São Paulo, 2014.

\begin{tabular}{lcc}
\hline \multicolumn{1}{c}{ Variables } & N & \% \\
\hline Personal use of ATMs & 30 & 100.0 \\
Possess cell phone & 26 & 86.6 \\
Make calls with cell phone & 19 & 63.3 \\
Only receive calls with cell phone & 7 & 23.3 \\
Total & 30 & 100.0 \\
\hline
\end{tabular}

Source: survey performed by researchers at IHESS, 2014. 
A troubling point of the study was whether elderly persons who used computers had received some kind of instruction regarding posture. In this case, none of the respondents reported having received postural instruction and/or any kind of training regarding using the computer, even in the environment of the institution, which confirms this concern and highlights the need for a physiotherapist to provide instruction regarding posture.

Table 4 below demonstrates the demographic results of the GDS and MMSE.

Table 4. Demographic details of sample and GDS and MMSE test data, Instituto Henrique da Silva Semente (IHESS). Indaiatuba, São Paulo, 2014.

\begin{tabular}{|c|c|c|}
\hline Variables & & Mean \% (n) \\
\hline \multicolumn{3}{|l|}{ Gender } \\
\hline Male & & $23.3(7)$ \\
\hline Female & & $76.6(23)$ \\
\hline \multicolumn{3}{|c|}{ Marital Status } \\
\hline Married & & $63.3(19)$ \\
\hline Single & & $36.6(11)$ \\
\hline Tests & Cut-off Point & Mean $(\min -\max )$ \\
\hline GDS & $5 \max$. & $2.67(0-8)$ \\
\hline MMSE & $23 \mathrm{~min}$. & $24.9(15-28)$ \\
\hline
\end{tabular}

Source: survey performed by researchers at IHESS, 2014.

The depression and cognition evaluation results provided excellent mean scores with an average of 2.67 for the GDS test and 24.9 for the MMSE test, respectively. It should be noted that all the tests were conducted in a collaborative climate, with the participation of all the elderly persons, which provided a high degree of accuracy.

The elderly persons felt satisfied with life, which was evident in the categories of personal satisfaction and interpersonal relationships of the GDS. As for the MMSE, the two results below the threshold of 23 were due to the elderly persons having difficulty in making the calculations, which does not properly indicate a cognitive deficit. The means were within the limits specified for the respective tests.

\section{DISCUSSION}

The study data demonstrates the largescale participation of women in the IHESS, corroborating the results of a study by Arantes ${ }^{8}$ that identified a greater frequency among the female public in related activities. Elderly women are considered to encourage the participation of older men, so much so that the seven male participants of the study were accompanying their wives during the course.

Of the reasons that led the elderly persons to attend the computer course at the IHESS, $46.6 \%$ mentioned digital inclusion as a tool of social integration, aiming to open up ways of communicating with friends and family. This 
result is an indicator that the elderly are seeking ways to interact with friends and family. The exchange of e-mail messages is the preference of many internet users. ${ }^{9}$ When they learn to use such devices, they communicate with relatives, children, grandchildren and great-grandchildren. Moreover, the importance of learning how to use a computer to type letters and send e-cards was noted, which gave everyone a sense of achievement. ${ }^{9}$ Learning such skills represented a source of pride for the vast majority of the elderly persons, as noted in a number of the reports of the respondents. These findings demonstrate that the elderly have a need to interact with society as widely as possible. Nowadays, society demands new behaviors, skills and languages from the elderly in order to use technology.$^{10}$ Included in this argument are simpler (basic) day to day technologies such as using TV remote controls, as well as more advanced skills which require more in depth knowledge, such as computers. In this context, it was possible during all the interviews to observe the pleasure the elderly persons took in participating in the computer course, both through their own learning and the expansion of their networks of social relationships. The statement below makes this idea clear:

"I think that we should be grateful every day, for our lives, for the opportunity to learn new technologies and spend time with our friends at IHESS." (Cecília, 78 years old)

The statement by Cecilia, which was not her real name, shows that learning is a two-way street in which the elderly persons have the opportunity for educational and social growth, discovering the true value of education as they learn and teach. ${ }^{11}$

The concerns given by the respondents regarding computer use were fear of breaking the computer, their children not allowing them to use it, or not knowing how to turn it on. These paradigms have developed since the time when the elderly persons begin to perform activities that were previously only intended for younger people. ${ }^{12}$ Thus, it is important that children, relatives and friends encourage the elderly to use these technologies, in order that they feel more comfortable and excited about the new discoveries of the digital age. The constant use and mastery of communication media among the elderly persons show the approximation, the interest and the connection to the technological world of such individuals, which bring benefits such as less apprehension and more confidence, due to the knowledge acquired. ${ }^{13}$

In terms of the involvement of the elderly with electronic devices and the assumption that this could incur a reduction in Activities of Daily Living (ADL), 83.3\% said they had participated in and still performed some kind of physical activity. Thus, we can consider that the sample group is active. Among the benefits of physical activity are the preservation of cognitive function, a distancing from the need for care, and reduced frailty. ${ }^{1}$ In this regard, the practice of physical activity becomes beneficial for the maintenance of functionality, reducing a number of deleterious effects in comparison with non-active aging. ${ }^{14}$

It was found that $66.6 \%$ of those interviewed demonstrated some type of difficulty in using the computer, with the most frequent being the use of the mouse, $60 \%$, followed by the keyboard, $46.6 \%$. Such results are understandable, as even young people, who are used to using such equipment, often experience some form of difficulty. Technological equipment does not always present a welcoming interface for the study universe and the characteristics of the elderly persons, particularly in terms of the size and type of font, the size of the icons, the contrast in colors, and the design of the interaction itself, which should be more intuitive. ${ }^{15}$ The function of double-clicking the mouse does not work when the mouse is in motion. This is a major problem for the elderly, who often cannot stop the mouse while they attempt to double-click. ${ }^{16}$

In terms of the other electronic equipment associated with digital inclusion, the results indicated that all the subjects used ATMs, highlighting the size of the buttons, with highlyvisible and easy to use letters and numbers. They 
also described how the illustrative drawings that appeared on the monitor helped with the operation, and said that the informative sounds of the machine aided understanding and brought security to the process. Other positive factors were described by those interviewed, such as the attention which bank staff give to the elderly persons when using the ATM. This is illustrated by one of the statements:

"Every time I go to get my pension at the bank, there's a young lady there to help me" and "The young lady always tells me to write my passcode down on a piece of paper so I won't miss out on my payment." "If there's a mistake, there's always someone from the bank to belp" (Alice, 74 years old).

Despite the significant number of elderly persons who reported using cell phones, $86.6 \%$ claimed that they found it difficult to use the appliances because of the size of the keys, in the case of analog devices. For those who used digital devices (with touch screens), the great difficulty of users was "scrolling" the screen. The elderly individuals had difficulties in performing activities that required fine hand motor skills. The decline of motor skills affects the ability to use the keyboard and mouse ${ }^{17}$ especially when associated with the loss of motor coordination, vision and other items that are inherent in the senescent aging process. ${ }^{18}$

Despite the difficulties reported, the elderly respondents demonstrated great happiness at participating in this process of digital inclusion and the chance to study and interact in a classroom with people of the same age range, contributing to a highly favorable environment, with approval from $100 \%$ of participants. In this regard, it is noteworthy that the sense of cooperation was predominant in the statements of the respondents, both with respect to their fellow students and students from other IHESS courses. This resulted in good social relations, particularly with friends and neighbors, getting along with family and spouses, being able to establish contacts with people and make new friends, and according to the elderly, having a good quality of life. ${ }^{19}$
Postural instruction is necessary for all computer users, not only the elderly, as an unsuitable position can result in musculoskeletal damage and impair the functional and motor capacity of individuals. With frequent computer use, people adopt a sitting posture on a daily basis, requiring less use of the lower limb muscles. ${ }^{20}$ The results showed that none of the respondents had had any kind of postural guidance for computer use. This shows a need for a physical therapist to provide physical therapy and geriatric guidance to elderly persons involved in computational learning activities and thereby mitigate the consequences resulting from the adopting of bad posture.

The present study could have been improved by a larger sample, based on previous studies and the appropriate metrics required to give the study greater relevance and consistency. However, the results obtained reveal, in a positive manner, that insertion into the digital age is a phenomenon with a tendency to grow and promote social integration.

\section{CONCLUSION}

The insertion of elderly persons into the digital era can be considered a reality, taking into account all the difficulties arising from the reduction of the physical and psychomotor ability of some older individuals who use such technologies. The large number of elderly persons interested in the computer course and other courses taught at IHESS reflect the extent to which this group of people are interested in integrating with society and that they want to be connected to the virtual world.

The survey revealed that the elderly may have several objectives in attending computer classes. Inclusion in the digital age means that the elderly person wishes to feel equal in a society which is increasingly engaged in the discovery of new technologies. Elderly persons have shown that they want to relate to people in their family, with friends, with their own colleagues at IHESS and 
finally with those who wish to interact with them. In addition, they reported having greater ease in communicating with people of the same age who have the same ideas and thoughts about life.

The lack of postural guidance is the only issue of concern for the quality of life of elderly people participating in social and educational institutions.
Environmental ergonomics could be studied and used as an intervention indicator by physical therapists to reduce the possible consequences of poor conditions in the use of electronic devices and activities of everyday life of the elderly. Overall, the objectives of the study were achieved and it provides results that will add to the information of other future studies.

\section{REFERENCES}

1. World Health Organization. Fact Sheet: Ageing and health [Internet]. Geneva: WHO; 2015 [acesso em 21 nov 2015]. Disponível em: http://www.who.int/ mediacentre/factsheets/fs404/en/

2. Brasil. Decreto no 6.214 , de 26 de setembro de 2007. Brasília: Presidência da República. Casa Civil; 2007. Disponível em: http://www.planalto.gov.br/ ccivil_03/_ato2007-2010/2007/decreto/d6214.htm

3. Pasqualotti A, Both A. Pessoa idosa, tecnologias de comunicação e interação e educação permanente. In: Ferreira AJ. Inclusão Digital de Idosos: a descoberta de um novo mundo. Porto Alegre: Edipucrs; 2008. p. 31.

4. Souza CC, Souza OC, Volpatto R. A ergonomia e a acessibilidade na inclusão digital em idosos. In: Ferreira AJ. Inclusão Digital de Idosos: a descoberta de um novo mundo. Porto Alegre: Edipucrs; 2008. p. 123.

5. São Paulo, Fundação Sistema Estadual de Análise de Dados. Informações dos Municípios Paulista [Internet]. São Paulo: SEADE; 2015 [acesso em 20 nov 2015]. Disponível em: http://www.imp.seade.gov. $\mathrm{br} /$ frontend/\#/perfil

6. Yesavage JA, Sheikh JI. Geriatric Depression Sacle (GDS): recent evidence and development of a shorter version. Clin Gerontologist 1986;5:165-73.

7. Folstein MF, Folstein SE, MacHugh PR. "Mini Mental State" A practical method for grading the cognitive state of patients for the clinician. J Psychiatr Res 1975;12:189-98.
8. Arantes RC. A longevidade na metrópole de São Paulo pelas notas de falecimento no Jornal da Tarde; 2004- 2005 [dissertação]. São Paulo: Pontifícia Universidade Católica de São Paulo; 2007.

9. Jorge RF. Usando o computador. Rio Total Rev Eletrôn [Internet] 2015 [acesso em 23 nov 2015]:1-2. Disponível em: http://www.riototal.com.br/felizidade/informatica01.htm

10. Kachar V. Longevidade: um novo desafio para a educação. São Paulo: Cortez; 2001.

11. Pasqualotti A, Both A. Pessoa idosa, tecnologias de comunicação e interação e educação permanente. In: Ferreira AJ. Inclusão Digital de Idosos: a descoberta de um novo mundo. Porto Alegre: Edipucrs; 2008. p. 34.

12. Ferreira AJ, Machado LM. Inclusão digital de idosos: desenvolvendo potencialidades. In: Inclusão Digital de Idosos: a descoberta de um novo mundo. Porto Alegre: Edipucrs; 2008. p. 46.

13. Wanzinack C, Bertola IP, Signorelli MC. Inclusão digital no litoral paranaense: uma proposta interdisciplinar. Divers@ Rev Eletrôn Interdisciplin 2013;6(1):1-16.

14. Organização Mundial de Saúde. Envelhecimento Ativo: uma política de saúde. Brasilia: Organização Pan-Americana de Saúde; 2005

15. Moro GHM. Uma nova interface para a inclusão digital na terceira idade [Dissertação]. São Paulo: PUC-SP; 2010 
16. Bean NC. Meeting the Challenge: Training an aging population to use computers. Southeastern Librarian 2003;51(3):1-11.

17. Ferreira AJ, Machado LR. Inclusão digital de idosos: desenvolvendo potencialidades. In: Ferreira AJ. Inclusão Digital de Idosos: a descoberta de um novo mundo. São Paulo: Edipucrs; 2008. p. 39.

18. Garcia EL, Banegas JR, Pérez-Regadera AG, Cabrera RH, Rodríguez-Artalejo F. Social network and health related quality of line in older adults: a populationbased astudy in Spain. Qual Life Res 2005;14(2):511-20.

19. Brandimiller PA. O corpo no trabalho: guia de conforto e saúde para quem trabalha em microcomputadores. São Paulo: SENAC; 1997.

20. Souza CC, Souza OC, Volpatto R. A ergonomia e a acessibilidade na inclusão digital em idosos. In: Ferreria JF. Inclusão digital de idosos: a descoberta de um novo mundo. Porto Alegre: Edipucrs; 2008. p. 125.

Received: March 03, 2015

Revised: May 02, 2016

Accepted: May 23, 2016 